\title{
RACE AND RELIGION
}

$T$ has long been recognized that there is a psychology not only of individuals, but also of groups. As with the hypothetical units of physicselectrons and atoms-so with the real units of the animal kingdom and of the human race, the group has a definite constitution and definite laws expressing its behaviour which are not the same as those which express the behaviour of the individuals of which the group is composed. Man is not merely an intelligent animal : he is also essentially a social animal, and, if the human race is to make progress, it is of supreme importance that the factors in social life which make for progress or for deterioration should be analysed out and critically discussed in their concrete historical setting.

This is the main aim of Professor McDougall's latest work, The Group Mind, * a book no less interesting than the other psychological works which Prof. McDougall has given us, and no less provocative of thought. It purports, in fact, to be the continuation of his Social Psychology, and assumes that the factors and principles of social life, as there laid down, are already familiar to the reader. These it now discusses from the point of view of the group. In the First Part the characteristics of different kinds of groups are set forth, notably those of the crude group or crowd and those of the most highly organized group-the army. Then there is a discussion of the group spirit, of the interrelation and interaction of groups, and of the peculiarities of certain types of group. The Second Part deals with the National Mind and Character, and with the influence upon it of racial qualities, of geographical conditions, of the increase of means of com-

*The Group Mind, by Wm. McDougall, F.R.S. (Cambridge University Press, pp. xvi, 304, 21s. net). 


\section{Blackfriars}

munication, of great leaders, of war, of different types of organization, of rivalry and intercourse, of ideas and of traditions. The Third Part discusses the factors that make for durability or change-progressive or regressive-during (I) the prehistoric or race-making period, and (2) the historic period.

The title of the book is curious, and implies a peculiar view on the part of the author, who rejectsprovisionally at least-the reality of a collective consciousness, but believes in that of the "collective mind or soul." His arguments here seem to us inconclusive. The collective mental life of the social aggregate is certainly " not merely the sum of the mental lives of its units," but neither is the collective behaviour of any aggregate of differentiated units the mere sum of the behaviours of those units, whether they be living or not. It is also mere tautology to assert that " a complete knowledge of the units, if and in so far as they could be known as isolated units, would not enable us to deduce the nature of the life of the whole," for in a whole the units are not isolated, but interrelated, otherwise they would not form a whole. To justify the term "group mind," Prof. McDougall must show that this entity is neither constituted by the units of which it is composed, nor yet by their interaction and inter-relationships, and this he has not done. The question is, however, irrelevant to the main issue, which in no wise suffers from the peculiar terminology which the author uses in the Title-page and Introduction, but for the most part drops in the body of the book.

Since the human race, as at present constituted, is divided into nations, Prof. McDougall rightly gives prominence to the national group. $\mathrm{He}$ also points out that the national group is a comparatively late product of the evolutionary process, apart from which it cannot be understood. Prior to national groups are 644 


\section{Race and Religion}

race groups, which in nations are combined and blended with greater or less success according as they are akin to, or radically different from, one another. Five factors contribute to the development of national character: (I) innate moral disposition, (2) innate intellectual capacities-which are racial and hereditary qualities, and (3) moral tradition, (4) intellectual tradition, and (5) social organization-which constitute national civilization, and operate not as innate tendencies, but $a b$ extra, as something in which the individual shares and under the influence of which he develops. The part played by these civilizing forces, moral and religious, intellectual and governmental, in the making of nations is immense, but racial qualities -evolved during the prehistoric period, but now innate-also play a part, determining which type of civilization will be acceptable and successful. Thus, the northern peoples of Europe, descended from Homo Europaus, are more energetic, more independent, more liberty-loving than the Southern peoples, originating in Homo Mediterraneus and Homo Alpinus; and a like difference obtains between the northern and southern peoples of Asia. Hence differences of social organization, of government, and of religion.

In this connection Professor McDougall makes an admission extremely significant from the evolutionary point of view. He rejects " root and branch the crude idea, which has a certain popular currency, that the development of civilization and of nations implies a parallel evolution of individual minds," and affirms that "there is no reason to suppose the present civilized peoples to be on the whole innately superior to their barbaric ancestors " (p. 203). "Our seeming intellectual superiority is a superiority of the traditional store of intellectual gains, a superiority of knowledge and of the instruments of the intellect, of language, and of the methods of mental operation by 02 


\section{Blackfiiars}

which knowledge is obtained, especially the mathe= matical and scientific methods in general." "No advance has taken place in intellectual capacity, but more probably some deterioration has already occurred" (pp. 262, 263). And yet mental qualities, and not merely their physiological correlates, are supposed to be evolved, and we are supposed to have started with the mental equipment of a ground-ape !

True, Prof. McDougall's statements, in support of which he quotes both authorities and facts, are made only of the historic period. Since we originated as ground-apes, and ultimately as amœbæ, yet have a mental equipment greater than either ground-apes or amœbæ, there must have been evolution of mental capacity somewhere. It is ascribed, therefore, quite naturally to the prehistoric period, about which, knowing nothing, we are free to speculate.

Yet what little we do know points in the other direction. Differences of mental constitution are attributed primarily to differences of energy, says Prof. McDougall, due for the most part to differences of climate, which operate both upon bodily functions and, through the senses, upon the imagination and higher mental processes. High temperature combined with moisture tends to depress vital activity; high temperature combined with dryness tends to promote violent spasmodic activity, but no enduring effort. A cold climate alone " seems to dispose towards sustained activity, and, when combined with much moisture, to a certain slowness." Add to this the effect of landscape, environment, and natural phenomena generally upon ideas and occupations, et voila the explanation, not indeed of our intellectual capacity, but of the lines along which it has developed and become diverse in different peoples. It is habit and tradition evolved under the influence of environment that differentiates us alike from the savage and from our more civilized $64^{6}$ 


\section{Race and Religion}

brethren. Fundamentally we are one and the same, are endowed with the same type of mind and inherit the same type of corpus, and, though differing considerably in the use we have made of them and hence in our civilizations, originally we all started scratch.

This conclusion, towards which Prof. McDougall's book points, but which the author does not draw, is, with respect to our origin, substantially in agreement with Christian teaching. We rejoice also that he should recognize the important part which religion has played, if not in the making, at any rate in the conserving of traditions which are vital to the progress of civilization. He admits that religious sanctions of morality have been acquired for the good of the race, and that the habit of reason and reflection, which in his view alone makes for progress, none the less also tends " to lead men to act for their own immediate welfare," and so is in need of the restraint which religion, looking further afield, is wont to exercise. But beyond this Prof. McDougall has scarce a good word to say for Christianity, and for Catholicism nothing but criticism. Not only does he ignorerightly enough as irrelevant to his subject - the natural or supernatural origin of religion, but he also ignores the influx of new ideas which came with Christianity and the immense stimulus they gave, and continue to give, to intellectual activity, to high ideals, and to the widening of man's outlook both practically and theoretically. For him religion is "essentially a system of supernatural sanctions for social conduct, for conduct conforming to the moral code of the society " in which it obtains. It does not originate this code, nor even modify it ; still less does it originate or modify ideals. It merely provides sanctions for a pre-existent code, and so tends to conserve it-a useful function, but one that tends to be, and often has been carried to excess, especially in the case of Catholicism, which 


\section{Blackfriars}

throughout her long history has been the "enemy of progress."

On this point Prof. McDougall is most emphatic. During the many centuries in which Catholicism swayed the peoples of Europe "little or no progress in civilization was effected, whereas rapid and accelerating progress has marked the last three centuries" (p. 268). "Religion, far from having been the sufficient cause or instrument of progress, was largely responsible for the stagnation of the Middle Ages, through sternly repressing the sceptical spirit and leading off men's minds from enquiry into natural laws, to the discussion of many topics on which it was impossible to achieve knowledge and which were necessarily barren of results making for human progress " (p. 274).

One would have expected this fifty years ago, but surely in these days when the vastness of mediæval knowledge is being re-explored, when physical science in many of her fundamental concepts is returning to those of mediæval times, when in the social sphere, as in the religious, mediæval principles are being rediscussed and revived, this kind of history and of reflection on history is somewhat out of date. One wonders, too, how Prof. McDougall proposes to square it with his own statement that " in the sixteenth century Spain" (then pre-eminently Catholic, and of all nations the least affected by either the Reformation or the Renaissance) " attained to a supreme position of power and grandeur among the nations of the world, such as has been rivalled by Rome alone in all history." The rise of Spain, we presume, took place in spite of her Catholicity: the latter accounts only for her fall, which Prof. McDougall attributes first to the alleged fact that " she made celibate priests of a very large proportion of those whose natural bent was towards the things of the mind, multiplying monastic orders excessively," and secondly to the alleged fact that " by 


\section{Race and Religion}

means of the Inquisition she destroyed with fire and sword or drove into exile through many generations" (during which by the way she must have been rising, not falling, for her fall was sudden) " all those who would not conform to her narrow creed, who combined intellectual power with independence and originality of spirit and a firm will " (p. 255).

Now I hold no brief for the persecutor, still less for the Spanish Inquisition; nor yet do I propose here to defend clerical celibacy. I would merely point out that Prof. McDougall himself provides us with ample means to defend both celibacy and persecution. Has he not told us that there has been no evolution of innate and hereditary qualities during the whole of the historic period, but that the whole of our development, our progress, our civilization, our culture, is due to the accumulation of knowledge and to improvement in the methods of acquiring it, toward which the celibate can contribute just as well, if not better, than the married man? Has he not also told us that the spirit of enquiry which leads men to question established customs and codes and religious sanctions is a " socially disruptive force," that it " cannot alone secure continued progress"; and that "wherever the progressive force has outrun the conservative, progress has been first rapid and then has come abruptly to an end "? Of Greece he writes that " it was the excessive seeking of individuals for their own power and glory, unrestrained by the customs and religious systems which their intellect had outgrown, that ruptured the bonds of society, plunged the State into war and civil strife, and eventually destroyed it by the extermination of the Greek aristocracy." The same is true, he says, of the mediæval Italian States. "Intellect outran and undermined morals, and progress was brought to an end " (p. 275). It would seem, then, on Prof. McDougall's own showing, that it is revolt 


\section{Blackfriars}

against the Church, not submission to her authority, that has hitherto put an end to progress. While, if free play of the intellect and the communion of different minds, combined with a certain conservatism and moral restraint, be the best conditions for progress, there would seem to be no place, as I read history, where these three conditions were more perfectly realized than in the cosmopolitan universities which the Middle Ages instituted, but the Reformation destroyed.

Brilliant as is The Group Mind in many respects, its author displays a strong prejudice against Catholicism which leads him to misinterpret facts and to generalize falsely thereon. Though admitting the decline of religion and drawing for us a discouraging picture of the prospects of modern civilization, he none the less glories in the Reformation which broke the bonds of "the more primitive religion" and so gave that free play to our intellectual faculties which has landed us in our present deplorable condition. He even attributes the success of the Reformation to the superior qualities of the Nordic race amongst which it prevailed, forgetful of the fact that for a thousand years the Nordic race was no less contentedly Catholic than the rest of Europe, and that Protestantism for the most part was not freely adopted, but was imposed by Lutheran princes and by Elizabeth with a no less heavy hand than that which Louis XIV used in sustaining the older religion. One wonders that a serious and scientific writer should in these days still contrast (p. 224) " the centralized official hierarchy which in Roman Catholic countries mediates between God and man " with that "direct communion with God" which the Nordic races are supposed to have substituted for it. And one wonders still more that he should maintain (p. 254) that " sincere and natural piety is far commoner in the Protestant countries than in the Roman Catholic ; that in the two countries, Italy and Spain, in which the 


\section{Race and Religion}

influence of the Roman Church has been greater than in any others, the people are now the least religiously minded of any in Europe ; that with them religion has become purely formal and external, that the mass of the people, though outwardly conforming, is absolutely irreligious ; that in fact this form of religion tends to exterminate itself in the long run by insisting upon that form of reproductive selection "-which is more commonly known as celibacy of the clergy.

In spite of these errors of fact and of false generalization, we recommend the book to those interested in race evolution, but would suggest as an antidote, where Catholicism is concerned, Belloc's Europe and the Faith, and to the author of The Group Mind would respectfully point out that he knows not the religion which he criticizes, neither in its teaching nor in its effects, but has studied it second-hand in sources which are manifestly polluted. For so earnest a seeker after truth one would have thought that the "group mind " of a Church which has endured for two thousand years and is still the largest in Christendom, in which our nations have been born and by which in large part they have been civilized, were worthy of a more careful consideration than that which as yet he has given it.

Leslie J. Walker, S.J. 